\title{
The Law and Politics of Constitutional Reform and Democratization in Hong Kong
}

Albert H.Y. Chen (Faculty of Law, University of Hong Kong) $)^{1}$

\section{Introduction}

Since 1997, the former British colony of Hong Kong has practiced autonomy as a "Special Administrative Region" (SAR) of the People's Republic of China under a constitutional arrangement known as "One Country, Two Systems" (OCTS). OCTS was first stipulated in the Sino-British Joint Declaration, a treaty signed in 1984 whereby Britian agreed to return Hong Kong to China in 1997. The Hong Kong Basic Law enacted by the Chinese National People's Congress in 1990, often known as Hong Kong's "mini-constitution”, constitutionalizes OCTS, grants to the Hong Kong SAR a "high degree of autonomy", and provides for the progressive democratization of Hong Kong.

The political system that has existed in post-1997 has been described as a "semi-democracy" (p 233). ${ }^{2}$ The Basic Law itself stipulates that the ultimate destination of the evolution of Hong Kong's political system is the election of the Chief Executive of the Hong Kong SAR by universal suffrage. However, this is "a democracy that might never come."3 "An authoritarian regime which has pre-committed itself to democracy is an inherently unstable regime, because it will be taken to task to deliver." ${ }^{4}$ Since 2003, a democracy movement has developed in Hong Kong that struggles for the speedy introduction of such universal suffrage. In 2007 , the Chinese government announced that such universal suffrage may be introduced in 2017. Since early 2013, a public debate has unfolded in Hong Kong on what should be the electoral system for this purpose. Pro-democracy politicians (commonly known in Hong Kong as the "pan-democrats") and activists are concerned that the electoral system, particularly the nomination process for candidates, would be such that only persons approved by the Chinese government could stand as candidates, and that the

\footnotetext{
1 This is a first draft of the paper. Some of the footnotes have not yet been completed. Parts of this paper (particularly Part II) are drawn from the author's chapter on "Development of representative government", in Johannes Chan and C.L Lim (eds), Law of the Hong Kong Constitution (Hong Kong: Sweet and Maxwell, 2011), chapter 8.

2 William H. Overholt, "Hong Kong: The Perils of Semidemocracy" (2001) 12(4) Journal of Democracy 5.

${ }^{3}$ Ma Ngok, Political Development in Hong Kong: State, Political Society, and Civil Society (Hong Kong University Press, 2007) p. 225.

4 H.C. Kuan, "Escape from Politics: Hong Kong's Predicament of Political Development" (1998) 21 International Journal of Public Administration 1423, p. 1444, quoted in Ma, ibid., p.226.
} 
election would not be conducted in accordance with international democratic standards. They call this "fake universal suffrage", and they argue that China must grant Hong Kong "genuine universal suffrage". Under the Basic Law, any constitutional reform such as the election of the Chief Executive by universal suffrage can only be introduced by a two-thirds majority in the Hong Kong legislature, in which the "pro-democracy" political parties occupy more than one-third of the seats.

The struggle for the realization of universal suffrage in the election of the Chief Executive in Hong Kong in 2017 provides a good case study of constitutional politics in a sub-national political community exercising autonomy and seeking to introduce constitutional reform and democratization. It is also particularly interesting because Hong Kong is an SAR of China, the major Communist Party-ruled polity in the contemporary world, while the aspirations of Hong Kong's democracy movement are towards Western-style liberal constitutional democracy. This paper seeks to tell this story of Hong Kong's quest for democratization, focusing particularly on the law and politics of Hong Kong's constitutional reform. It suggests that whether such constitutional reform will occur or not is unpredictable at present, and that the success or failure of the constitutional reform depends crucially on Beijing's policy towards the pro-democracy political parties in Hong Kong.

This paper consists of the following parts. Part I examines the constitutional and legal provisions governing Hong Kong's political system and its development. Part II reviews briefly the movements towards democratization that have taken place since the establishment of the Hong Kong Special Administrative Region in 1997. Part III consider developments since early 2013, when a social movement known as the "Occupy Central" campaign developed to struggle for the realization of genuine universal suffrage in the election of the Chief Executive of Hong Kong. The paper will focus particularly on the positions of the democracy activists in Hong Kong, as well as the stance of the Central Government in Beijing. Finally, Part IV will conclude by evaluating the prospects for Hong Kong's democratization.

\section{Hong Kong's Political System: Constitutional and Legal Provisions}

The British Empire acquired the colony of Hong Kong - the geographical territory of which is now the Hong Kong Special Administrative Region (HKSAR) of the People's Republic of China (PRC) - from China in three stages: the cession of Hong Kong Island by the Qing Emperor in China to Britain in 1842 after the "Opium War"; the cession of Kowloon Peninsula (to the north of Hong Kong Island) by the 
Qing to Britain in 1860 after the Anglo-French forces invaded Peking; and the 99-year lease by the Qing to Britain of the "New Territories" (north of Kowloon) in the midst of the foreign powers" "scramble for concessions in China" in 1898.

Although the British transplanted to Hong Kong its common law and its tradition of the Rule of Law, it did not introduce in Hong Kong the British style of parliamentary democracy or the "Westminster mode" of government. The British colonial government ruled the colony by means of a kind of "soft authoritarianism". Power was concentrated in the hands of the Governor (appointed directly by the British Crown) and senior expatriate officials of the colonial government of Hong Kong appointed by the Governor, who formed the top tier of a civil service bureaucracy recruited largely from the local Chinese populace. The legislature known as the Legislative Council - consisted of senior government officials and "unofficial members" chosen by the Governor from the local British and Hong Kong business and professional elite and appointed to sit in the Legislative Council. The system was described as "administrative absorption of politics" or "government by consultation and consensus". Since the 1950s, Hong Kong enjoyed rapid economic growth as one of the "Four Little Dragons" of East Asia (together with Taiwan, Singapore and South Korea). Hong Kong's population consisted largely of migrants from the Chinese mainland and their descendants, particularly migrants who fled to Hong Kong during the communist revolution in the mainland in the late 1940s. They were willing to accept colonial rule in Hong Kong instead of struggling for democratization and decolonization, which was unlikely to provoke the PRC (established in 1949 after the defeat of the Nationalist Party government by the Chinese communists) government to claim Hong Kong from the British.

As the British "lease" over Hong Kong's New Territories would expire in 1997, British Prime Minister Margaret Thatcher visited Beijing in 1982 and initiated negotiations with the PRC Government on Hong Kong's constitutional future. The result was the Sino-British Joint Declaration signed at the end of 1984. The Joint Declaration provided for Hong Kong's return to China in 1997. The PRC undertook to allow Hong Kong to practice a high degree of autonomy as a "Special Administrative Region" (SAR) of the PRC after 1997. There would be "Hong Kong people ruling Hong Kong" instead of the PRC government sending its Communist Party cadres to rule Hong Kong. Hong Kong would be permitted to retain its existing economic, social and legal systems (including capitalism, private property, the English common law and existing provisions for the protection of human rights and civil liberties) in accordance with Deng Xiaoping's concept of "One Country, Two Systems": Hong 
Kong would become an integral part of the "One Country" of China, but the Chinese mainland and Hong Kong would practice different "systems" - socialism and capitalism respectively.

The Joint Declaration contained detailed provisions on the systems and policies to be practiced by the HKSAR. The Joint Declaration is a treaty that is binding on the Chinese and British governments in international law, but the PRC would need to translate its provisions into its domestic law so as to provide a legal basis for the operation of the HKSAR. The drafting of such a domestic law began in 1985 and was completed in 1990, when the National People's Congress (NPC) of the PRC enacted the Basic Law of the HKSAR of the PRC -- the product of nearly five years of work including two public consultation exercises in 1988 and 1989 on its drafts. This Basic Law would serve as a "mini-constitution" for Hong Kong after 1997. It provides for the constitutional relationship between the HKSAR government and the central government in Beijing; it defines the structure, mode of formation and powers of the HKSAR government; it guarantees the rights and liberties of Hong Kong people; and it also sets out the social and economic policies and systems to be practiced in the HKSAR.

As regards Hong Kong's political system, the Joint Declaration had only provided for it briefly, while the Basic Law provides for the details. One of the main areas of controversy during the drafting of the Basic Law was the extent to which the political system of the HKSAR should be democratic, given that the colonial political system at the time the Joint Declaration was signed in 1984 was hardly democratic in that neither the executive nor the legislature was elected by the people of Hong Kong. The Joint Declaration did contemplate some degree of democratization of this colonial political system. On the mode of selection of the Chief Executive of the HKSAR - who would replace the colonial Governor as the head of the Hong Kong government, the Joint Declaration provided that the Chief Executive "shall be selected by election or through consultations held locally and be appointed by the Central People's Government". As regards the legislature, which was an entirely appointed body at the time of the Joint Declaration, the Joint Declaration provided that the HKSAR legislature "shall be constituted by elections", but did not elaborate further on the precise mode of election. As regards the relationship between the executive and the legislature, the Joint Declaration provided that the executive "shall be accountable to the legislature". 
The provisions of the Basic Law regarding the design of the political system of the HKSAR may be summarized as follows. The Basic Law declares that the "ultimate aim" 5 of the political evolution of Hong Kong is the election of both the Chief Executive and all members of the Legislative Council (LegCo) by universal suffrage. However, it is also provided that such political evolution depends on "the actual situation in the HKSAR" and "the principle of gradual and orderly progress". 6 The Basic Law itself provides for a progressive increase in the number of directly elected members (i.e. members elected by universal suffrage in geographical constituencies in different parts of Hong Kong, as distinguished by members elected by "functional constituencies" to be discussed below) of LegCo from 20 (out of a total membership of 60 ) in the first LegCo to 24 in the second LegCo, and then to 30 in the third LegCo. ${ }^{7}$ As regards the selection of the Chief Executive, it is provided that the first Chief Executive would be chosen by a Selection Committee of 400 members, and the second and third Chief Executives elected by an Election Committee of 800 members. Given that the Joint Declaration provided that the Chief Executive may be chosen either by election or consultation, and did not make it clear that the elections to the Legislature must be direct election rather indirect election or election by "functional constituencies", the gains for democracy in the making of the Basic Law may be recognised. ${ }^{8}$

An important feature of the political system prescribed by the Basic Law is that it is not a static one but an evolving one, and the logic and mechanism of its evolution is provided for in the Basic Law itself. The ultimate aim of universal suffrage, the principle of gradual and orderly progress and the phased increase in the number of directly elected legislators have been mentioned above. Another important characteristic of the political system established by the Basic Law is its openness to

5 Basic Law arts. 45, 68.

6 Ibid.

7 Annex II to the Basic Law; and the Decision of the NPC on the Method for the Formation of the First Government and the First Legislative Council of the HKSAR. In the first and second LegCos, 10 and 6 members respectively were to be elected by an election committee. In the first, second and third LegCos, 30 members were to be elected by functional constituencies.

8 It is also noteworthy in this regard that in the Basic Law of the Macao Special Administrative which is in most respects almost identical to the Hong Kong Basic Law, there is no mention whatsoever of the direction of political evolution or any eventual destination of universal suffrage for the election of the Chief Executive and all members of the legislature. This testifies to the relative strength of the democracy movement in Hong Kong in the 1980s. 
change after 2007. Annexes I and II to the Basic Law expressly provide that the methods for electing the Chief Executive and LegCo may change after 2007. They also expressly provide for the procedure for such constitutional change, which involves the support of a two-thirds majority in LegCo, the Chief Executive's consent and the approval of (in the case of a change in the electoral method for the Chief Executive) or "reporting for the record" to (in the case of a change in the electoral method for LegCo) the National People's Congress Standing Committee (NPCSC).

The Basic Law, though enacted already in 1990, would only come fully into effect in 1997 upon the establishment of the HKSAR. In the "transition period" between 1984 (the year the Joint Declaration was signed) and 1997, the British colonial government continued to govern Hong Kong. It introduced a series of measures for Hong Kong's democratization in preparation for the handover of Hong Kong to China in 1997. Some of these measures were contested by the PRC, which argued that constitutional reforms in Hong Kong during the transition period must "converge" with the model of the HKSAR political system prescribed by the Basic Law. However, Beijing did not object to all of the political reforms introduced by the colonial government. Actually, some of the political institutions created by the colonial government in the transition period were recognized by and incorporated into the Basic Law itself. The most important of such institutions was that of "functional constituencies", the origins of which will now be elaborated.

In 1985, the colonial government introduced its first major measure towards Hong Kong's democratization. This was the creation of 24 elected seats in the LegCo (see Appendix I of this paper for the total number of seats, the modes of election and their subsequent changes). Twelve of these seats were elected by electoral colleges comprising the District Boards, the Urban Council and Regional Council, which were largely consultative bodies at local levels. The other twelve were elected by "functional constituencies" consisting of business and professional groupings, such as chambers of commerce, industrialists' federations, trade unions and members of professions such as lawyers, doctors, engineers and teachers. The original logic of functional constituencies as explained by the colonial government was that they represented sectors of society from which appointed unofficial members of LegCo were formerly drawn, and in the course of democratization, it was appropriate that the corporate bodies or individual members of these sectors would elect their own representatives into LegCo. These two modes of election of LegCo members were incorporated into the Basic Law when it was enacted in 1990. Thus the first LegCo of the HKSAR would consist of 20 members 
elected by universal suffrage, 30 members elected by functional constituencies, and 10 elected by an electoral college. The number of members elected by universal suffrage would increase to 30 in the third LegCo (see Appendix I).

Functional constituencies also have a role to play in the election of the election committee for the Chief Executive of the HKSAR. As prescribed in Annex I to the Basic Law, the election committee would consist of persons from four sectors, with equal numbers of members from each sector. The sectors are (a) business (comprising mainly corporate voters in different commercial, financial and industrial fields), (b) professional bodies, (c) labour and other social sectors, and (d) the political sector (including legislators, Hong Kong deputies to the NPC and the Chinese People's Political Consultative Conference, etc). Thus in the election committee of 800 members, there were 200 members from each of the four sectors.

\section{Post-1997 Movements Towards Democratization}

In the first few years of the history of the HKSAR, elections by the election committee to the office of the Chief Executive and elections of the LegCo by the various modes mentioned above took place in accordance with the relevant provisions of the Basic Law. A major turning point in the post-1997 history of Hong Kong was the Hong Kong government's attempt to enact a national security law for the purpose of the implementing Article 23 of the Basic Law, which requires the HKSAR to enact laws on treason, secession, sedition, subversion and protection of state secrets. The legislative exercise was aborted after a march of an estimated half a million people on 1 July 2003 in opposition to the bill for the proposed law. ${ }^{9}$ The bill was supported by the "pro-China" camp (also known as the "pro-establishment" camp) in Hong Kong politics but opposed by the "pro-democracy" camp (also known as the "pan-democrats"), which led the social movement against the bill. With their prestige

9 See generally Fu Hualing et al. (eds.) National Security and Fundamental Freedoms: Hong Kong's Article 23 Under Scrutiny (Hong Kong University Press, 2005); Ngok Ma, "Civil Society in Self-Defense: The Struggle Against National Security Legislation in Hong Kong” (2005) 14 Journal of Contemporary China 465: the author points out that "The 1 July protest had profound implications for future political development of Hong Kong. ... In the long run, the movement encouraged local political participation and breathed new life into the democracy movement. ... The struggle against Article 23 ... witnessed an unprecedented mobilization by professionals and the middle class. ... the democratic genre is definitely out of the bottle after 1 July, which promptly brings the struggle over a full-fledged democracy to the center stage again from 2004 to 2007.” (pp. 481-482) 
bolstered by their success in opposing the national security bill, the pro-democracy politicians of Hong Kong launched a movement to demand the speedy democratization of the HKSAR. ${ }^{10}$ In late 2003 and early 2004, a number of pro-democracy assemblies and demonstrations were held and were attended by tens of thousands of people. Pro-democracy politicians found in the Basic Law a powerful source of legitimacy for their demands. As mentioned above, the provisions of the Basic Law itself allows change to the existing "undemocractic" system for the election of the third-term Chief Executive in 2007 and the fourth-term LegCo in 2008. Thus the democrats' slogan was "double universal suffrage": the introduction of universal suffrage for the election of the Chief Executive in 2007, and universal suffrage for the election of all legislators in 2008.

The democracy movement was met with Beijing's most significant intervention on Hong Kong affairs since the establishment of the HKSAR. Departing from its normal practice of holding one session of meetings once every two months, the NPC Standing Committee (NPCSC) held two successive sessions in April 2004. At the end of the first session, the NPCSC on 6 April issued an Interpretation of the Basic Law. It elaborates upon Annexes I and II to the Basic Law by stipulating a procedure for initiating changes to the relevant electoral methods: the Chief Executive should first submit a report to the NPCSC on whether there is a need to introduce electoral change, whereupon the NPCSC will decide the matter in accordance with Articles 45 and 68 of the Basic Law. After this interpretation, Chief Executive Tung Chee Hwa submitted a report to the NPCSC on 15 April. ${ }^{11}$ Another session of the NPCSC was immediately convened to consider the report, and on 26 April the NPCSC promulgated its Decision on the matter. The Decision rules out the introduction of universal suffrage for the Chief Executive and all legislators in 2007 and 2008 respectively, but permits political reforms in 2007 and 2008 within certain parameters (e.g. the proportion of directly

${ }^{10}$ See generally Ming Sing, "Public Support for Democracy in Hong Kong" (2005) 12(2) Democratization 244 (explaining the upsurge in public support for democracy in Hong Kong since the rally of 1 July 2003).

11 Report by the Chief Executive of the Hong Kong Special Administrative Region to the Standing Committee of the National People's Congress on whether there is a need to amend the methods for selecting the Chief Executive of the Hong Kong Special Administrative Region in 2007 and for forming the Legislative Council of the Hong Kong Special Administrative Region in 2008 (Hong Kong Government, 2004); the Second Report of the Constitutional Development Task Force: Issues of Principle in the Basic Law Relating to Constitutional Development (Hong Kong Government, 2004). 
elected legislators to those elected by functional constituencies shall remain unchanged). ${ }^{12}$

After the NPCSC Decision, the Constitutional Development Task Force of the Hong Kong Government conducted public consultations on political reform for 20072008, leading to the publication of its Fifth Report in October $2005 .^{13}$ This was a major initiative on the part of Mr Donald Tsang, who had succeeded Mr Tung Chee Hwa following the latter's resignation from the office of Chief Executive in spring 2005. The Fifth Report proposed the election of the Chief Executive in 2007 by an Election Committee of 1600 persons (which would include, inter alia, all members of the District Councils (formerly known as District Boards), and the expansion of LegCo in 2008 from 60 members to 70 members (including five new seats to be directly elected by universal suffrage and five new seats elected by District Councillors). Under Annexes I and II to the Basic Law, the adoption of the proposed reform would require the support of a two-thirds majority in LegCo. On 21 December 2005, the proposal was defeated by 24 "pan-democrats" in LegCo voting against it, mainly on the ground that it was not democratic enough (e.g. the District Councillors entitled to vote under the proposed system included not only elected Councillors but also appointed Councillors), and that the Government failed to provide a timetable for the introduction of universal suffrage. ${ }^{14}$

After the defeat of the political reform proposal in December 2005, discussion on political development continued to be carried out in the Committee on Governance and Political Development of the Commission on Strategic Development of the Hong Kong Government. The Committee was established by Tsang in late 2005 partly in response to criticisms that the Government was not able to provide any timetable for the introduction of universal suffrage. It was on the basis of the deliberations in this

12 See generally A.H.Y. Chen, “The Constitutional Controversy of Spring 2004” (2004) 34 HKLJ 215; Johannes Chan and Lison Harris (eds.), Hong Kong's Constitutional Debates (Hong Kong Law Journal Limited, 2005).

13 The Fifth Report of the Constitutional Development Task Force: Package of Proposals for the Methods for Selecting the Chief Executive in 2007 and for Forming the Legislative Council in 2008 (Hong Kong Government, 2005).

14 See generally A.H.Y. Chen, "The Fate of the Constitutional Reform Proposal of October 2005" (2005) 35 HKLJ 537. 
Committee that the Green Paper on Constitutional Development ${ }^{15}$ was published on 11 July 2007, initiating a three-month consultation on the subject.

On 12 December 2007, the Government published its Report on Public Consultation on the Green Paper on Constitutional Development. ${ }^{16}$ At the same time, Mr Donald Tsang, the Chief Executive of the HKSAR, submitted his report to the NPCSC on "the Public Consultation on Constitutional Development and on whether there is a need to amend the methods for selecting the Chief Executive of the HKSAR and for forming the Legislative Council of the HKSAR in 2012". ${ }^{17}$ On 29 December 2007, the NPCSC enacted its Decision on Issues Relating to the Methods for Selecting the Chief Executive of the HKSAR and for Forming the Legislative Council of the HKSAR in the Year 2012 and on Issues Relating to Universal Suffrage (the NPCSC Decision). ${ }^{18}$ The most significant provisions may be set out as follows:

(a) In 2012, neither the Chief Executive (CE) nor all legislators may be elected by universal suffrage. In 2012, the ratio (50:50) of legislators elected by universal suffrage to those elected by functional constituencies will remain unchanged. Subject to these parameters, the electoral arrangements for the CE and LegCo in 2012 may be amended in accordance with the "principle of gradual and orderly progress" as provided for in the Basic Law. ${ }^{19}$

(b) At its meeting the NPCSC was "of the view that" "the election of the fifth CE of the HKSAR in the year 2017 may be implemented by the method of universal suffrage; that after the CE is selected by universal suffrage, the election of the LegCo of the HKSAR may be implemented by the method of electing all the members by universal suffrage". ${ }^{20}$

(c) "At an appropriate time prior to" the election of the CE or of all legislators by universal suffrage, the five-step procedure prescribed in Annexes I and II to the

15 Hong Kong: Government Logistics Department, 2007.

${ }^{16}$ Hong Kong: Government Logistics Department, 2007. The Green Paper on Constitutional Development was published on 11 July 2007, and the consultation period for the Green Paper ended on 10 October 2007.

17 Hong Kong: Government Logistics Department, 2007.

18 Gazette of the HKSAR Government, Special Supplement No 5 to Gazette Extraordinary No 48/2007 (31 December 2007) pp. E48 (Chinese version), E49 (English version). For a commentary on the decision, see A.H.Y. Chen, “A New Era in Hong Kong’s Constitutional History” (2008) 38 HKLJ 1.

19 Point 1 of the 4-point decision.

20 This passage is in the introductory paragraph and not in the 4-point decision. 
Basic Law and the NPCSC Interpretation of 6 April 2004 should be followed: (1) the CE making a report to the NPCSC, (2) the NPCSC rendering a decision thereon, (3) a Government bill for electoral reform being passed by a two-thirds majority in LegCo, (4) the CE consenting to the bill, and (5) the bill being reported to the NPCSC for approval or for the record.

(d) At its meeting the NPCSC was "of the view that" the nominating committee (referred to in the Basic Law) for candidates for election of the CE by universal suffrage "may be formed with reference to the current provisions regarding the Election Committee in Annex I to the Hong Kong Basic Law". ${ }^{21}$ The nominating committee shall in accordance with democratic procedures ${ }^{22}$ "nominate a certain number of candidates for the office of the CE, who is to be elected through universal suffrage by all registered electors of the HKSAR, and to be appointed by the Central People's Government". ${ }^{23}$

On the basis of the 2007 Decision of the NPCSC, Mr Donald Tsang introduced the political reform exercise of 2009-2010, which was designed to revise the models for the election of the Chief Executive and the Legislative Council in 2012. This exercise began with the publication in November 2009 of the Government's Consultation Document on Methods for Selecting the Chief Executive and for Forming the Legislative Council in 2012, ${ }^{24}$ which put forward proposals (the 2009 Proposal) for electoral reforms in 2012 largely similar to, but designed to be an improved version of,

${ }^{21}$ Quotation from the first of the two concluding paragraphs of the Decision.

22 The reference to "democratic procedures" is not new but exists in art. 45 of the Basic Law (which provides for "the selection of the Chief Executive by universal suffrage upon nomination by a broadly representative nominating committee in accordance with democratic procedures"). The meaning of this phrase is uncertain and has become controversial in the context of the debate on universal suffrage for the election of the $\mathrm{CE}$ in Hong Kong. For example, it has been suggested that the phrase means that all members of the nominating committee should vote for the purpose of selecting a number of candidates who may then participate in the election of the CE by universal suffrage. Under Annex I, art.4 of the Basic Law and the Chief Executive Election Ordinance (as it stood at the time of the 2007 NPCSC Decision), nomination by not less than 100 members of the 800 -member Election Committee is sufficient to enable a person to become a candidate in the election of the $\mathrm{CE}$.

${ }^{23}$ Quotation from the first of the two concluding paragraphs of the Decision.

${ }^{24}$ The document was published on 18 November 2009 and was available in both hard copy and electronically. 
the reform proposals (the 2005 Proposal) contained in the Fifth Report of the Constitutional Development Task Force that were vetoed by the pan-democrats in LegCo in December 2005.

The 2009 Proposal was similar to the 2005 Proposal in at least three ways: (1) the proposed expansion of the size of the Election Committee for the CE; (2) the proposed increase of the total number of seats in LegCo from 60 to 70; and (3) the prominent role proposed for District Councillors in the election of LegCo and in the Election Committee. There were however two main differences between the two proposals. First, the expanded Election Committee under the 2009 Proposal will have 1200 members instead of 1600 members. Secondly, under this proposal the District Councillors who would participate in the election of the five additional seats in LegCo and of relevant additional seats in the Election Committee would only include elected members of District Councils and exclude the appointed members (who comprise approximately 20 per cent of the membership of the District Councils).

More precisely, the expanded Election Committee in the 2009 Proposal would be elected by the four sectors of society each of which elected 200 members of the Election Committee under the existing system. Each of these sectors would elect 300 members under the 2009 Proposal. As regards the additional 100 seats allocated to the fourth sector (the "political sector"), the 2009 Proposal suggested that "most of them"25 may be elected by the elected members of the District Councils. On the issue of the "nomination threshold" for candidates for Chief Executive, it was proposed that it would remain at one-eighth of the total number of members of the Election Committee (i.e. 150 among the 1200-member committee, as compared to the existing rule of 100 among the 800-member committee). ${ }^{26}$

After considering the views of members of the public collected during the three-month consultation period for the Consultation Document, the Government on 14 April 2010 formally announced its Package of Proposals for the Methods for Selecting the Chief Executive and for Forming the Legislative Council in 2012-a constitutional reform proposal (the Reform Package) that was basically the same as that proposed in the Consultation Document. The motions for the relevant amendments to Annexes I and II of the Basic Law for the purpose of implementing the

\footnotetext{
25 Paragraph 4.13 of the Document.

${ }^{26}$ Paragraph 4.21 of the Document.
} 
Reform Package were formally submitted to LegCo on 7 June 2010 for debate and voting before the end of June 2010.

Since the publication of the Consultation Document, the pan-democrats had publicly stated their opposition to the Reform Package on the ground that it was not democratic enough. The scenario as of 7 June 2010 was that the motion for the Reform Package would be vetoed by the pan-democrats - a repetition of what happened in December 2005. ${ }^{27}$ To the surprise of most observers, the situation suddenly changed on 14 June 2010, when Mr Henry Tang, Chief Secretary of the HKSAR Government, met with Mr Albert Ho, Chairman of the Democratic Party (DP) - one of the pan-democratic political parties, and asked him whether the DP would support the Government's LegCo motion for constitutional reform if the Government were to modify the Reform Package and accept the DP's counter-proposal regarding the five additional District Councils functional constituency seats being elected (after candidates have been jointly nominated by several elected District Councillors) by all voters in Hong Kong who do not already have the right to vote in any existing functional constituency. ${ }^{28}$ In the light of the affirmative answer given by $\mathrm{Mr} \mathrm{Ho}$, Chief Executive Donald Tsang announced on 21 June the Government's acceptance of the DP's counter-proposal as a modification to its original Reform Package. Although not all the pan-democrats in LegCo supported the modified Reform Package, the Government with the support of the DP secured the necessary two-thirds majority in LegCo for the modified Reform Package to be passed by LegCo on 24-25 June.

The history of the failed political reform in 2005 and the successful reform in 2010 thus illustrates the nature and operation of the constitutional dynamics of democratization in the HKSAR. Under the Basic Law and the NPCSC's interpretation of it in 2004, any electoral reform in Hong Kong can only be initiated with the

\footnotetext{
27 See generally Albert H.Y. Chen, "The Fate of the Constitutional Reform Proposal of October 2005" (2005) 35 HKLJ 537.

28 Approximately 200,000 persons had the right to vote in existing functional constituencies. According to the DP's proposal, more than three million registered voters would be enfranchised with regard to the five newly created LegCo functional constituency seats, and all voters in Hong Kong will have two votes - one in a geographical constituency, and one in a functional constituency. The Government's Reform Proposal involved, inter alia, the creation of 10 additional seats in LegCo, 5 of which being elected by universal suffrage in geographical constituencies, and 5 being elected by a new functional constituency consisting of elected District Councillors.
} 
consent of the NPCSC, and the basic features of the reform - which have to be proposed by the HKSAR Government -- must win the support of a two-thirds majority in the Legislative Council before the reform can go ahead. Thus whether a particular reform will materialize depends on the collective will of the Central Government, the HKSAR Government and the Hong Kong Legislative Council (LegCo). In the LegCo, the pan-democrats (who on the average secured approximately $60 \%$ of the popular votes for the half of LegCo seats that were elected by universal suffrage) have always secured more than one-third of the seats in LegCo; thus they have the power of veto on any political reform. In 2005, they vetoed the political reform package proposed by the government on the ground that it was not democratic enough. In 2010, the government's proposal would have been vetoed again on the ground that it was not democratic enough - but for a last-minute major amendment of the proposal.

Thus the paradox of the constitutional dynamics of Hong Kong's democratization is that the pan-democrats have the voting power to defeat any government proposal for democratization which they consider to be not democratic enough and thus unsatisfactory, even though the pan-democrats do not themselves have the power to initiate any democratic reform or to secure its passage in LegCo. Given the provisions on democratization in the Basic Law and the demands for democratization from civil society in Hong Kong, the central government and the Hong Kong government have been willing to introduce moderate measures in the direction of democratization. The pan-democrats, in reliance on their power of veto, may seek to bargain for a better deal. However, whether they succeed or not depends on whether there is a sufficient incentive and will on the part of the central government and the Hong Kong government to make a deal and to move Hong Kong forward on the path of democratization. In case the bargaining fails and no deal is reached, there would be no forward movement at all and the status quo of the political system would be maintained. In this case, both the pan-democrats and the government would be losers, assuming that the interests of both the pan-democrats and the government would be served by a movement towards democratization.

\section{The Struggle for "Genuine" Universal Suffrage Since Early 2013}

To the pan-democrats, the political reform of 2010 was only of limited significance, since Hong Kong's political system is still far away from achieving the goals of what they call "double universal suffrage" - the election of the Chief 
Executive and of all members of LegCo by universal suffrage. As mentioned above, the National People's Congress Standing Committee (NPCSC) had in December 2007 set the timetable for the realization of these goals: the Chief Executive may be elected by universal suffrage in 2017, and thereafter the whole of the LegCo may also be so elected.

Mr Donald Tsang, Chief Executive at the time, described this NPCSC Decision as "a most important step for Hong Kong's constitutional development". ${ }^{29}$ The setting of the "timetable" for further democratization in Hong Kong was indeed a significant development. Yet it should be noted that some of the most controversial issues regarding Hong Kong's political development have remained unresolved. In particular, since Article 45 of the Basic Law provides that candidates for election of the Chief Executive by universal suffrage have to be nominated by "a broadly representative nominating committee in accordance with democratic procedures", there have been concerns about whether the universal suffrage promised with regard to the election of the Chief Executive in 2017 is genuine or "fake" universal suffrage: pan-democrats are concerned that the "nomination threshold" and the "screening mechanism" for candidates for the Chief Executive in the context of the operation of the nominating committee would be such that only pro-China politicians (as opposed to the pan-democrats) would get nominated by the nominating committee. Furthermore, there were concerns as to whether the universal suffrage for the election of all legislators promised by the NPCSC Decision of 2007 means the abolition of functional constituencies, which is a major goal that pan-democrats have fought for. ${ }^{30}$

29 “Donald Tsang's statement on the NPC decision", South China Morning Post, 30 December 2007, p.3.

${ }^{30}$ Mr Zhang Xiaoming, Deputy Director of the Hong Kong and Macau Affairs Office of the State Council, suggested in his speech in Hong Kong on 29 December 2007 that the existence of functional constituencies for the purpose of LegCo elections is not necessarily inconsistent with the concept of universal suffrage: see "2017 Suffrage Goal Hinges on Progress by 2012”, South China Morning Post, 30 December 2007, p.2; "NPC: Functional Constituencies Consistent with Principle of Universal Suffrage", Ming Pao, 30 December 2007, p.A2 (in Chinese). See generally Christine Loh and Civic Exchange (eds.), Functional Constituencies: A Unique Feature of the Hong Kong Legislative Council (Hong Kong University Press, 2006). 
As the NPCSC has set the target date for the implementation of universal suffrage for the election of the Chief Executive at the year 2017, a third exercise in political reform (following the first two exercises in 2005 and 2010 respectively) would need to be conducted in 2013-15 to work out the precise model for such election. Pro-democracy political activists in Hong Kong started in early 2013 to prepare for this exercise. A milestone in this regard was the publication on 16 January 2013 of an article by Mr Benny Tai, associate professor in the law school of the University of Hong Kong, on the idea of an "Occupy Central" campaign to pressurize the central government and the Hong Kong government to introduce a model for universal suffrage that is consistent with international human rights standards. The idea was widely circulated on the Internet and received much media attention, snowballing into a real "Occupy Central" campaign supported by many civil society groups and the pro-democracy politicians in Hong Kong. "Occupy Central" in this context refers to demonstrators practicing civil disobedience and occupying the Central District - the central business district of Hong Kong - to paralyse it in case the government fails to come up with a model for universal suffrage that complies with international standards on free and fair elections. After months of deliberation, the Occupy Central Movement proposed on 6 May 2014 three models for election of the Chief Executive by universal suffrage for public consideration, all including the element of nomination of candidates by prescribed numbers of citizens.

Another major development in the struggle for democracy was the formation on 21 March 2013 of the Alliance for True Democracy, consisting of all the pan-democrats in the LegCo, all the "pro-democracy" political parties and some civil society organisations. The objective of the Alliance is to promote the realization of "genuine" universal suffrage in Hong Kong. After months of deliberation, the Alliance proposed on 8 January 2014 a "three-track" model for the election of the Chief Executive by universal suffrage - the three tracks being nominations by citizens (also known as "civic nominations"), by political parties and by the nominating committee respectively.

Earlier, on 17 October 2013, Mr C.Y. Leung, the Chief Executive of the HKSAR, had announced the establishment of a three-person "Task Force on Constitutional Development" which would launch a public consultation exercise on the electoral reforms for the LegCo and the Chief Executive to be elected in 2016 and 2017 respectively. The exercise formally commenced on 4 December 2013 with the publication of the Consultation Document on "Let's talk and achieve universal 
suffrage", initiating a 5-month consultation period which ended on 3 May 2014. During the consultation period, many political parties and civil society groups, including those which are "pro-China" and those which are "pro-democracy", put forward their proposed models for the nomination and election of the Chief Executive in 2017.

Since March 2013, the central government of the PRC has, through various widely publicized speeches of its senior officials and of legal scholars close to the government, made known its stance on and baseline for this exercise in political reform in Hong Kong. It has been repeatedly said that any model for the election of the Chief Executive must be based on and consistent with the provisions of the Basic Law and the relevant decisions of the NPCSC. In this regard, doubt has been cast on whether the mode of "civic nominations" of candidates for the Chief Executive election proposed by the pan-democrats, the Alliance for True Democracy and the Occupy Central Movement is consistent with the provision on nominations by the nominating committee ("NC") in Article 45 of the Basic Law.

Central government officials have also pointed out that nominations by the NC are "institutional nominations" (i.e. nominations by the NC as an institution) expressing the "collective will" of the committee, which are different in nature from the procedure of joint nominations by individuals used by the existing Election Committee for the election of the Chief Executive. It has also been stressed that the Chief Executive must be a "patriot" who "loves the nation and loves Hong Kong", and the Central Government will not appoint as Chief Executive someone who is "confrontational" towards the Central Government and attempts to change the socialist political system in mainland China. In March 2014, Mr Zhang Dejiang, Chairman of the NPCSC, said that the design of the model for universal suffrage for the Chief Executive of the HKSAR is a matter that concerns the "sovereignty, security and developmental interests" of the PRC, and that the context for the universal suffrage to be practiced in the HKSAR is that of a local election and not a national election - hence the models for national elections in other countries are not necessarily appropriate for Hong Kong. Subsequently, it was elaborated that if someone who is not a "patriot" becomes the Chief Executive of the HKSAR, the security interests of the PRC might be prejudiced.

The key difference between Beijing's position on universal suffrage for Hong Kong's Chief Executive and that of the pan-democrats seems to be as follows. Beijing would like to ensure that the candidates for election by universal suffrage to the office of the Chief Executive are all acceptable, trustworthy and appointable from Beijing's 
point of view, in the sense that they are not "confrontational" towards the Central Government or ideologically opposed to the "socialist political system" being practiced in mainland China. The system of nominations of candidates by a nominating committee as provided for in Article 45 of the Basic Law enables this objective to be achieved if the majority of the members of the nominating committee are "pro-China" or "patriots". Thus it was suggested in the 2007 Decision of the NPCSC that the composition of the nominating committee may be based on that of the existing election committee for the Chief Executive. The political reality has been that with the 4-sector composition of the election committee and its members being largely elected by functional constituencies, the majority of its members are indeed "pro-China", and those who are pan-democrats or sympathetic to them only constitute a minority in the election committee.

On the other hand, the pan-democrats are firmly opposed to any "screening" to be performed by the nominating committee for the purpose of preventing persons who have considerable public support among Hong Kong voters (such as leading members of the pan-democrats) but are not "patriots" in Beijing's eyes from becoming candidates for election by universal suffrage to the office of the Chief Executive. In their view, this would be "fake" universal suffrage and inconsistent with international standards of democracy which prohibit unreasonable restrictions on the right to be a candidate in an election (such as restrictions or discrimination based on a person's political opinion). "Genuine" universal suffrage, in their view, requires a truly competitive election in which candidates with different platforms and political opinions may freely and fairly compete for votes. Given that the pan-democrats have always obtained a majority of the popular votes for the half of the LegCo seats that were elected by universal suffrage (the other half being elected by functional constituencies), they believe that any nomination system for the election of the Chief Executive by universal suffrage which makes it impossible for their leaders to be nominated as candidates would not be genuine universal suffrage.

The above-mentioned difference between Beijing and the pan-democrats in Hong Kong on the issue of universal suffrage can only be fully understood in the light of history and orientation of the "pan-democrats" or "pro-democracy" politicians as a political force in Hong Kong, to which we now turn. Since the 1980s and until now, politicians and activists in Hong Kong have been divided into two camps - the pro-China camp (now commonly known as the "pro-establishment" camp) and the 
pro-democracy camp (now commonly known as the "pan-democrats"). ${ }^{31}$ The division has been intensified by the experience of various major political events, such as the Beijing student movement in 1989, the political reform introduced by Governor Chris Patten in the 1990s (which was opposed by Beijing but supported by the pan-democrats), the establishment of the Provisional Legislative Council at the time of the 1997 handover (which was opposed by the pan-democrats), the "right of abode" litigation leading to the first-ever interpretation of the Basic Law by the NPCSC (which was opposed by the pan-democrats), the Article 23 legislative exercise leading to the abortion of the National Security Bill in 2003, the 2004 interventions by the NPCSC on political reform in Hong Kong, the 2005 Interpretation by the NPCSC on the term of office of the Chief Executive, the defeat of Donald Tsang's political reform proposal in December 2005, the 2007 NPCSC Decision on political development in Hong Kong and Donald Tsang's original political reform proposal of 2009.

In each of these events, the pan-democrats opposed the Chinese Government's position. The pan-democrats or "pro-democracy" camp has been labelled "the opposition camp" by some pro-China commentators in Hong Kong. ${ }^{32}$ They are considered to have consistently opposed the policies of the Chinese Government towards Hong Kong, particularly those with regard to the development of the political system in Hong Kong. Some of them are considered hostile to communist rule in China. Some of them are leaders of the Hong Kong Alliance in Support of Patriotic Democratic Movements of China, which was founded in 1989 and has continued to operate in Hong Kong after 1997, organising annual vigils and protests demanding the rehabilitation of the Beijing student movement of 1989 and the end of one-party rule. Some of them attended the ceremony in Norway for the award to Liu Xiaobo-a leading dissident in China - of the Nobel Peace Prize in 2010, a ceremony which China urged all Governments friendly to it to boycott. Some of them have been denied the issue of a "huixiang zheng", a passport-like document which Hong Kong

\footnotetext{
31 See generally S.K. Lau and H.C. Kuan, "Partial Democratization, 'Foundation Moment' and Political Parties in Hong Kong” (2000) 163 China Quarterly 705.

32 The term “opposition camp” or “opposition faction” (反對派) was first used by Mr Donald Tsang to refer to the pro-democracy camp when the latter vetoed Tsang's political reform proposal in December 2005. The term was popularised among pro-China commentators after the publication of a lengthy article in the pro-China newspaper Wen Wei Po: “The Hong Kong 'Democracy Camp' is actually the Opposition Camp” (香港「民主派」實為反對派), Wen Wei Po, 29 December 2005, pp.A8-A9.
} 
permanent residents who are Chinese nationals need to produce in order to enter China. Some of them are also suspected of having close relationships with foreign Governments or foreign NGOs active in promoting democratization globally. Yet ever since direct election by universal suffrage was introduced for a portion of LegCo seats in 1991, the pan-democrats have consistently succeeded to capture approximately 60 per cent of the popular votes for that portion of LegCo seats which were filled by elections by universal suffrage. ${ }^{33}$ The Chinese Government's concern is therefore that if unrestricted elections by universal suffrage were introduced in Hong Kong, the office of the Chief Executive and the majority of LegCo seats would be captured by the pan-democrats.

There seems to exist a fundamental difference in the understanding of "autonomy" and of the relationship between "autonomy" and "democracy" on the part of the Chinese Government on the one hand and the pro-democracy political parties, politicians and civil society in Hong Kong on the other hand. The pro-democracy camp's understanding of the autonomy of Hong Kong may be termed a Western liberal democratic and legalistic understanding of autonomy. It is believed that as in the case of, say, the people in a state of the United States who can freely elect their state legislature and state governor, the people of Hong Kong should also be able to freely elect by universal suffrage their Chief Executive and all members of their Legislature. In a liberal democratic federal state like the United States, the state legislature and state governor may on their own exercise all powers within their constitutional limits, and the federal government may not interfere with the exercise of such powers. In a similar vein, the democrats in Hong Kong believe that so long as the elected Government of Hong Kong stays within the scope of its power under the Basic Law, the Central Government should leave it alone and it is none of the Central Government's business to intervene or otherwise influence it. Thus there is no legitimate reason why Beijing should not allow a free, fair and truly competitive election to the office of the Chief Executive in Hong Kong. And the appointment of the Chief Executive by the Central Government after his or her being elected by the people of Hong Kong should be no more than a formality.

Beijing's understanding of the autonomy of the HKSAR is however not the same. It has always been stressed that the power of appointment of the Chief Executive is a substantive power and not merely formal or ceremonial. This is to ensure that the Chief

\footnotetext{
33 The pro-China camp has consistently captured $30-40 \%$ of these popular votes.
} 
Executive is someone acceptable to and trusted by Beijing. Beijing has stressed that Hong Kong's system of government is an "executive-led" system and must not be allowed to become a "legislative-led" one. The emphasis on executive-led government may be understood in the light of the fact that it is the Executive (including the Chief Executive and the principal officials), not the Legislature, that is appointed by Beijing and enjoys the confidence and trust of, and derives powers and authority from, Beijing. As is evident in Deng Xiaoping's speeches on "one country, two systems" in Hong Kong (which were re-published ${ }^{34}$ in 2004 during the campaign to stress the idea of “patriots ruling Hong Kong”), China's understanding of Hong Kong's autonomy is that of "Hong Kong people ruling Hong Kong", the majority of those Hong Kong people exercising the power to rule Hong Kong being patriots - people whom the Chinese Government and the Chinese Communist Party consider to be patriots and thus their political allies for the purpose of ruling Hong Kong. This kind of thinking should be understood in the context of the Chinese Communist Party's long tradition of "united front work", 35 in which friendly political relations are cultivated between the Communist Party and non-communists whom the Party considers to be trustworthy and reliable for the purpose of forming a political alliance to achieve a common goal. Such united front work has been actively undertaken in Hong Kong by the Chinese authorities both before and after the 1997 Handover. $^{36}$

It is noteworthy that Deng Xiaoping said in the context of "patriots ruling Hong Kong" that "direct elections" may not necessarily produce the right people for this purpose. $^{37}$ Thus democracy is not an ultimate value or goal in itself. It is only a means for the purpose of choosing the right people to rule Hong Kong. And the process of democratisation in Hong Kong is subject to the overriding principle of "patriots ruling Hong Kong". The conflict between this vision of Hong Kong's democratization and the pan-democrats vision is encapsulated in the current debate on the model for the election of the Hong Kong Chief Executive by universal suffrage in

\footnotetext{
${ }^{34}$ Deng Xiaoping On “One Country, Two Systems" (Joint Publishing, 2004), which is the English translation of《鄧小平論「一國兩制」》published by the same publisher. See particularly the speeches at pp.13, 23 and 67 of this English book.

35 See generally Lyman P. Van Slyke, Enemies and Friends: The United Front in Chinese Communist History (Stanford University Press, 1967).

${ }^{36}$ See Ma, fn 74 above, Chapter 3; Jamie Allen, Seeing Red: China's Uncompromising Takeover of Hong Kong (Butterworth-Heinemann Asia, 1997) Chapter 3.

37 Deng Xiaoping On “One Country, Two Systems”, note 34 above, pp.75-76.
} 
2017.

\section{Conclusion}

The realization of the election of the Chief Executive of the HKSAR by universal suffrage in 2017 will be no easy task. If politics is the art of the possible, the project of realizing such universal suffrage would be a supreme test of the skills, acumen, courage and wisdom of Hong Kong politicians in practising this art. Would it be possible to devise a model for the Chief Executive election which both recognizes the democratic aspirations of the pan-democrats and preserves the prerogatives of the Central Government in ensuring that the Chief Executive of the HKSAR will not be someone confrontational towards the Central Government? Would Beijing ultimately agree to a nominating system with a relatively low "nomination threshold" so that pan-democrats may put forward their candidate(s) for the election of the Chief Executive by universal suffrage? Would the pan-democrats, or at least some of them, accept an electoral model which falls short of their present demands, so that the model secures the requisite two-thirds majority in LegCo? The answers to these questions will be known in the coming year.

My own assessment of the situation is as follows. Although the pan-democrats have pushed strongly for civic nominations so as to bypass the nominating committee which is likely to be dominated by "pro-China" forces, civic nominations will in all likelihood be rejected by the Hong Kong and Beijing governments as being inconsistent with Article 45 of the Basic Law. It is likely that the government will put forward a model for electing the Chief Executive by universal suffrage in which the nominating committee would be constituted in a manner similar to the existing election committee for electing the Chief Executive, but democratized by expanding the electoral base of voters (at present approximately 200,000 persons) for the committee and the number of members of the committee. The key issue in the institutional design of the nomination system would be the "nomination threshold", i.e. how many members of the nominating committee need to vote for a particular person in order for this person to become a candidate for election by universal suffrage. The more democratic is the manner of constituting the nominating committee and the lower the nomination threshold, the greater is the chance that at least some of the pan-democrats may be persuaded to support the proposal so that it can be passed by a two-thirds majority in LegCo.

In the final analysis, whether Beijing will agree to an electoral model that is 
acceptable to the pan-democrats and that can be passed by LegCo is likely to depend on a cost-and-benefit analysis of introducing elections of the Chief Executive by universal suffrage in Hong Kong. The benefit would be to be seen to honour the promise made in the 2007 Decision of the NPCSC and in the Basic Law, and to win the support of Hong Kong people who aspire towards democracy. Furthermore, some believe that the Hong Kong Government will become more effective if its Chief Executive is elected by universal suffrage and thus has greater legitimacy to govern Hong Kong. On the other hand, an electoral model that is acceptable to the pan-democrats would be one in which the pan-democrats would have a reasonable chance of getting their candidate(s) being nominated by the nominating committee as candidate(s) in the Chief Executive election by universal suffrage. For Beijing, agreeing to such an electoral model means to accept that there is a chance that a pan-democrat would be the winner in the election. Beijing will have to assess the likelihood of this scenario materializing, and to consider how to deal with this scenario should it materialize. Would it appoint the pan-democrat as Chief Executive? Or would it decline to make an appointment - a power which it has under the Basic Law, so that another election should be held? What would be the nature and magnitude of the political crisis in Hong Kong should this happen? How would such a crisis (taking into account its likelihood and its magnitude) compare with the crisis (including, for example, "Occupy Central") that would be precipitated by the electoral model favoured by Beijing being vetoed by LegCo so that Hong Kong people's hopes for universal suffrage in 2017 are dashed? These, then, are likely to be the considerations which Beijing would take into account in deciding on the model for universal suffrage for the Hong Kong Chief Executive in 2017.

\section{Appendix I}

Composition of Legislative Council 1985-2012

\begin{tabular}{|c|c|c|c|c|c|}
\hline & $\begin{array}{c}\text { Geogra- } \\
\text { phical } \\
\text { election }\end{array}$ & $\begin{array}{c}\text { Functional } \\
\text { consti- } \\
\text { tuencies }\end{array}$ & $\begin{array}{c}\text { Election } \\
\text { committee/ } \\
\text { electoral } \\
\text { college }\end{array}$ & $\begin{array}{c}\text { Appointed } \\
\text { non-gover } \\
\text { nment } \\
\text { members }\end{array}$ & $\begin{array}{c}\text { Government } \\
\text { members }\end{array}$ \\
\hline 1985 & nil & 12 & 12 & 22 & 10 \\
\hline 1988 & nil & 14 & 12 & 22 & 10 \\
\hline
\end{tabular}




\begin{tabular}{|c|c|c|c|c|c|}
\hline 1991 & 18 & 21 & nil & 17 & 3 \\
\hline 1995 & 20 & 30 & 10 & nil & nil \\
\hline 1997 & nil & nil & nil & $\begin{array}{c}{[60 \text { elected }} \\
\text { by electoral } \\
\text { committee }]\end{array}$ & nil \\
\hline 1998 & 20 & 30 & 10 & nil & nil \\
\hline 2000 & 24 & 30 & 6 & nil & nil \\
\hline 2004 & 30 & 30 & nil & nil & nil \\
\hline 2008 & 30 & 30 & nil & nil & nil \\
\hline 2012 & 35 & 35 & nil & nil & nil \\
\hline
\end{tabular}

